\title{
PERINATAL CARE IN A NORTHEASTERN BRAZILIAN STATE: STRUCTURE, WORK PROCESSES, AND EVALUATION OF ESSENTIAL NEWBORN CARE COMPONENTS
} Cuidado perinatal em um estado do nordeste brasileiro: estrutura, processos
de trabalho e avaliação dos componentes do essential newborn care Rafaella Willig de Quadrosa,* (D), Lara Damiani Cabrala $\mathbb{B}$, Chaiana Esmeraldino Mendes Marcona (D)

Tubarão, January 29, 2020.

To: Revista Paulista de Pediatria

The article by Bezerra et al. reveals significant distortions regarding perinatal care in Sergipe. Despite showing data above the national average on aspects such as the presence of an on-duty pediatrician 24 hours a day and the availability of equipment for maternal and neonatal resuscitation in all maternity hospitals, the state still has deficits in several essential newborn care (ENC) measures. ${ }^{1}$

With respect to ENC components, the presence of companions from prenatal to postpartum was observed in only $18 \%$ of cases, and early skin-to-skin contact was noted in $41 \%$ of deliveries. However, only $33.1 \%$ of mothers breastfed in the first hour of life. Therefore, this letter aims at providing data from other Brazilian states in order to encourage improvements in actions for newborn care proposed by the World Health Organization (WHO). ${ }^{1}$

We emphasize that the reality of the Brazilian Northeast concerning ENC principles differs from the situation observed in the Southern region of the country, as shown in the study by Velho et al. The authors found that $88.1 \%$ of pregnant women were accompanied at all times by a person of their choice during delivery and that $51.8 \%$ of them had skin-to-skin contact with their child. This scenario was highlighted by a model of best practices in obstetric care, which promotes increased humanization during childbirth, resulting from the adoption of a greater proportion of evidence-based practices. ${ }^{2}$

Nevertheless, breastfeeding in the first hour after birth is still unsatisfactory throughout Brazil — rates similar to those of Sergipe $(33.1 \%)$ — , not following the guideline proposed by the Ministry of Health that recommends this practice, which alone is the strategy that most prevents infant deaths. In the first hour of life, the child is in a quiet-alert state - quiet but alert and with eyes wide open - , as if paying attention. ${ }^{3}$

In the state of Sergipe, physical and structural care is considered adequate, but the ENC components are below those proposed by the WHO. The poor prevalence of breastfeeding in the first hour of life portrays the reality not only of this Northeastern state but also of Brazil. ${ }^{1}$

Given the seriousness of the above issues, measures to encourage the humanization of perinatal care must be implemented for neonatal and maternal benefits.

\section{REFERENCES}

1. Bezerra FD, Menezes MA, Mendes RB, Santos JM, Leite DC, Kassar SB, et al. Perinatal care in a northeastern Brazilian state: structure, work processes, and evaluation of the components of essential newborn care. Rev Paul Pediatr. 2019;37:140-8. http://dx.doi.org/10.1590/19840462/;2019;37;2;00003

2. Velho MB, Brüggemann OM, McCourt C, Gama SG, Knobel R, Gonçalves AC, et al. Obstetric care models in the Southern Region of Brazil and associated factors. Cad Saude Publica. 2019;35:e00093118. http://dx.doi.org/10.1590/0102$311 \times 00093118$

3. Brazil - Ministério da Saúde [homepage on the Internet]. Secretaria de Atenção à Saúde - Departamento de Atenção Básica. Saúde da criança: aleitamento materno e alimentação complementar. Brasília: Ministério da Saúde; 2015 [cited 2019 Aug 21]. Available from:: <http://bvsms.saude.gov. br/bvs/publicacoes/saude_crianca_aleitamento_materno_ cab23.pdf> 


\section{AUTHOR'S RESPONSE LETTER}

\section{AUTHOR'S RESPONSE LETTER Carta-resposta}

\section{Felipa Daiana Bezerra, ${ }^{a *}\left(\mathbb{D}\right.$, Maria Alexsandra da Silva Menezes $\mathbb{B}^{\mathbb{D}}$, Rosemar Barbosa Mendes $^{a}$ (D) José Marcos de Jesus Santos ${ }^{b}$ (D), Debora Cristina Fontes Leite ${ }^{\mathbb{D} \text {, }}$ Samir Buainain Kassard ${ }^{\mathbb{D}}$, Ricardo Queiroz Gurgel ${ }^{a}$ (D)}

Dear colleagues, we are delighted to receive your comments on our article. We agree that Sergipe, like most of Brazil, falls short when it comes to the practices that make up ENC.

One of the paradoxes presented in our article is the presence of an adequate hospital structure for perinatal care (equipment for resuscitation and pediatricians in the delivery room, for example) associated with the low frequency of breastfeeding in the first hour of life and early skin-to-skin contact. ${ }^{1}$

Another study of national data that evaluated ENC practices highlighted the negative effect of cesarean sections on early skin-to-skin contact and breastfeeding in the first hour of life, regardless of maternal characteristics and hospital structure. The high rates of cesarean section indeed seem to contribute to the delay in mother-newborn contact. This finding is unfortunate, as these measures are important for reducing infant mortality.
These data emphasize the urgent need for changes in pregnancy, labor, and delivery care. Another significant result is the low adherence to ENC components in Sergipe, compatible with results found in the North and Northeast regions. ${ }^{2}$ In Brazil, the scenario is similar, but with regional disparities. A study by Velho et al. concluded that, just as in Sergipe, interventional obstetric care still predominates in the South region, with high rates of cesarean sections, but with greater adherence to ENC practices in public hospitals. ${ }^{3}$

As the frequency of cesarean delivery in Brazil remains high, changing the perinatal care model currently practiced is crucial. The WHO recommendations related to ENC are simple and inexpensive. They also have a positive effect on reducing neonatal mortality, showing that the implementation of best practices is closer to the commitment of multidisciplinary teams in wanting to change the Brazilian perinatal scenario than to the investment in technologies.

\section{REFERENCES}

1. Bezerra FD, Menezes MA, Mendes RB, Santos JM, Leite DC, Kassar SB, et al. Perinatal care in a northeastern Brazilian state: structure, work processes, and evaluation of the components of essential newborn care. Rev Paul Pediatr. 2019;37:140-8. http://dx.doi.org/10.1590/1984-0462/;2019;37;2;00003

2. Menezes MA, Gurgel R, Bittencourt SD, Pacheco VE, Cipolotti R, Leal MC. Health facility structure and maternal characteristics related to essential newborn care in Brazil: a cross-sectional study. BMJ Open. 2018;8:e021431. http:// dx.doi.org/10.1136/bmjopen-2017-021431

3. Velho MB, Brüggemann OM, McCourt C, Gama SG, Knobel R, Gonçalves AC, et al. Obstetric care models in the Southern Region of Brazil and associated factors. Cad Saude Publica. 2019;35:e00093118. http://dx.doi.org/10.1590/0102$311 \times 00093118$

*Corresponding author. E-mail: felipadai@gmail.com (F.D. Bezerra).

aUniversidade Federal de Sergipe, Aracaju, SE, Brazil.

bUniversidade Federal de Sergipe, Lagarto, SE, Brazil.

Universidade Tiradentes, Aracaju, SE, Brazil.

¿Universidade Estadual Ciências da Saúde de Alagoas, Maceió, AL, Brazil.

Received on October 9, 2019.

(c) 2020 Sociedade de Pediatria de São Paulo. Published by Zeppelini Publishers.

This is an open access article under the CC BY license (http://creativecommons.org/licenses/by/4.0/). 